\title{
SISTEM INFORMASI AKADEMIK BERBASIS WEB MENGGUNAKAN PENDEKATAN BERORIENTASI OBJEK PADA JURUSAN TEKNOLOGI INFORMASI POLITEKNIK NEGERI PADANG
}

\author{
Oleh : \\ Ronal Hadi,Yulherniwati, Rika Idmayanti \\ Jurusan Teknologi Informasi, Politeknik Negeri Padang \\ ronalhadi@yahoo.com
}

\begin{abstract}
Department of Information Technology Padang State Polytechnic growing rapidly, the number of students and the amount of data will increase too. However, these conditions will bring complex problems to the department to manage it in quantitative and qualitative way. How complicated the problems faced when there are a lot of data that needs to be processed, and if it goes wrong it needs a long time to find, fix and change it. To minimize the errors and redundancies in processing the data, the department requires an academic information system. This system will manage student grades, final assignment and job training data at Information Technology Department. This web based Academic Information System was develop by using object oriented concept and JAVA especially J2EE technology as programming language and MYSQL Server as database. This system also design by using UML(Unified Modeling Language).
\end{abstract}

Keyword : Academic Information System, Object Oriented, UML, Java

\section{PENDAHULUAN}

Sistim informasi adalah sekumpulan elemen yang berkerja secara bersama sama baik secara manual maupun berbasis komputer dalam melaksakan pengolahan data yang berupa pengumpulan, penyimpanan, pemrosesan data untuk menghasilkan informasi yang bermakna dan berguna bagi proses pengambilan keputusan

Saat ini pada Politeknik Negeri Padang sedang menerapkan teknologi informasi komputer (TIK) untuk kehadiran proses belajar mengajar. Untuk aspek sistim akademik lainnya seperti pengelolaan nilai, pengelolaan Tugas Akhir (TA) dan Praktek Kerja Lapangan (PKL) digunakan aplikasi spreadheet. Kelemahan pengelolaan dengan cara seperti ini adalah tidak terintegrasinya data sehingga sering terjadi duplikasi penginputan dan pengolahan data sehingga tidak efisiennya pekerjaan input data. Masalah lain yang disebabkan pengolahan data secara manual adalah tingginya kecendrungan kesalahan input dan pengolahan data serta sulit dan lamanya pembuatan dan pemeriksaan kebenaran laporan. Dari kenyataan tersebut, dirasakan perlunya pengembangan sistem informasi akademik berbasis wab jurusan teknologi informasi politeknik negeri padang untuk pengelolaan nilai, TA dan PKL yang dapat mengatasi kelemahan tersebut. Dalam pengembangan sistem informasi ini akan digunakan pendekatan berorientasi objek agar sistem informasi dapat dikembangkan 
untuk selanjutnya dengan lebih mudah. Bahasa pemograman yang digunakan adalah Java dengan teknologi J2EE dan basis data menggunakan MySQL Server.

\section{STUDI LITERATUR Sistem Informasi}

Sistem informasi adalah sekumpulan elemen yang bekerja secara besama-sama baik secara manual maupun berbasis komputer dalam melaksanakan pengolahan data yang berupa pengumpulan, penyimpanan dan pemrosesan data untuk menghasilkan informasi yang bermakna dan berguna bagi proses pengambilan keputusan(Jogianto, 2005).

\section{Teknologi Web}

WWW (World Wide Web) atau web adalah suatu ruang informasi yang dipakai oleh pengenal global yang disebut Uniform Resource Identifier (URI). WWW sering dianggap sama dengan internet secara keseluruhan, walaupun sebenarnya ia hanyalah bagian dari padanya (Darma \& Sehenia,2009 ).Melalui Web, dapat diakses informasi-informasi yang tidak hanya berupa teks tapi juga bisa berupa gambar,suara,video dan animasi.dokumendokumen informasi disimpan atau dibuat dalam format HTML (Hypertext Markup Language).

Web dapat dikategorikan menjadi 2 ,yaitu : Web Statis dan Dinamis atau interktif. Web statis adalah web yang menampilkan informasi yang bersifat statis (tetap). Sedangkan web dinamis adalah web yang menampilkan informasi serta dapat berinteraksi dengan user yang sifatnya dinamis. Sehingga untuk membuat web dinamis dibutuhkan kemampuan pemograman web yang terdiri dari server side programming dan client side programming .
Browser adalah aplikasi yang digunakan untuk mencari dan menampilkan informasi melalui jaringan internet. Kelebihan dari aplikasi yang dijalankan melalui browser adalah dapat diakses dari tempat yang jauh, bahkan dari tempat yang secara geografis sangat jauh dari tempat dimana aplikasi tersebut berada. Pendistribusian aplikasi yang berjalan dibrowser tidak membutuhlan spesifikasi hardware/software yang rumit.

\section{Teknologi Objek}

Teknologi objek menganalogikan sistem aplikasi seperti kehidupan nyata yang didominasi oleh objek. Orang, mobil, dan komputer merupakan objek. Objek memiliki atribut seperti orang-orang yang dapat berjalan, berbicara, berteman dan sebagainya. Sistem yang dibangun dengan teknologi objek memiliki fleksibilitas yang tinggi terhadap perubahan karena menggunakan konsep komponen yang digunakan kembali .

Ada empat prinsip dasar dalam pemograman berorientasi objek (Hermawan, 2003) yaitu sebagai berikut :

a. Abstraksi memfokuskan perhatian pada karakteristik objek yang paling penting dan saling dominan yang bisa digunakan untuk membedakan objek tersebut dengan objek yang lainnya

b. Enkapsulasi menyembunyikan banyak hal yang terdapat dalam objek yang tidak perlu diketahui dengan objek yang lainnya.

c. Modularitas membagi sistem yang rumit menjadi bagian-bagian yang lebih kecil yang biasa mempermudah untuk memahami dan mengelola objek.

d. Hirarki berhubungan dengan abstraksi dan modularitas yaitu pembagian berdasarkan urutan dan pengelompokkan. 


\section{Unified Modeling Language (UML)}

UMLadalah bahasa standar yang di unakan untuk menjelaskan dan memvisualisasikan artifak dari proses analisis dan desain berorientasi objek (Hermawan,2003). UMLmenyediakan standar pada notasi dan diagram yang bisa digunakan untuk memodelkan suatu sistem .UML dikembangkan oleh Grady Booch, Jim Rumbaugh dan Ivar Jacobson. UML menjadi bahasa yang bisa digunakan untuk berkomunikasi dalam persektif objek antara user dengan developer, antara developer analisis dengan developer desain dan antara developer desain dengan developer pemrograman.

\section{Bahasa Pemrograman Java}

Java dikembangkan oleh sun microsystem pada agustus1991 dengan nama semula oak. Pada januari 1995, karena nama oak dianggap kurang komersial, maka diganti dengan Java.(Abdul Khadir, 2005:2)

Menurut Isak Rickyanto (2002:16), Java adalah bahasa pemrograman tingkat tinggi yang memiliki karakteristik: sederhana ,berorientasi objek, dapat didistribusikan dengan murah, aman, portabel, multi threading, dinamik dan netral terhadap arsitektur hardware

$$
\text { Java merupakan program }
$$

berorientasi objek (OOP), dengan kata lain rancangan java merupakan suatu teknik yang memusatkan rancangan pada data (objek) dan interface (prasetyo,2004)

Paltform Java 2 (Hariyanto, 2003) tersedia dalam 3 edisi untuk keperluan berbeda yaitu sebagai berikut:

a) Standard edition (J2SE) menyediakan lingkungan pengembangan yang kaya fitur, stabil, aman, cross-platform.

b) Enterprise edition (J2EE) menyediakan kakasa untuk membangun dan menjalankan multitier enterprise edition.

c) Micro edition (J2ME) untuk beragam produk elektronik seperti pager, smart card, cell phone handheld PDA dan set- top-box. Aplikasi J2ME juga dapat bekerja dengan J2SE dan J2EE.

\section{METODOLOGI PENELITIAN}

Rancang bangun Sistem Informasi Akademik Berbasis web ini dilakukan dengan tahap-tahap sebagai berikut :

- Studi Pustaka

- Analisis

- Perancangan

- Implementasi

\section{Analisis Kebutuhan dan Perancangan}

Analisis dan desain yang dilakukan adalah analisis dan perancangan berorientasi objek. Proses analisis bertujuan memahami masalah yaitu dengan memahami apa yang sebenarnya ada dalam dunia nyata. Sementara proses desain bertujuan memahami pemecahan masalah yang didapatkan dari proses analisis yaitu dengan mengusulkan secara detail sistem komputer seperti apa yang perlu dibangun untuk mengatasi suatu masalah. Hasil dari analisis dan desain ini adalah model sistem dalam bentuk UML usecase diagram. Untuk perancangan usecase diagram Sistem Informasi Akademik dibagi menjadi dua model yaitu Model Use Case Diagram pengelolaan tugas akhir dan praktek kerja lapangan dan model Use Case Diagram pengelolaan nilai mahasiswa. 


\section{Perancangan UML Use Case Diagram Pengelolaan Tugas Akhir dan Praktek Kerja Lapangan}

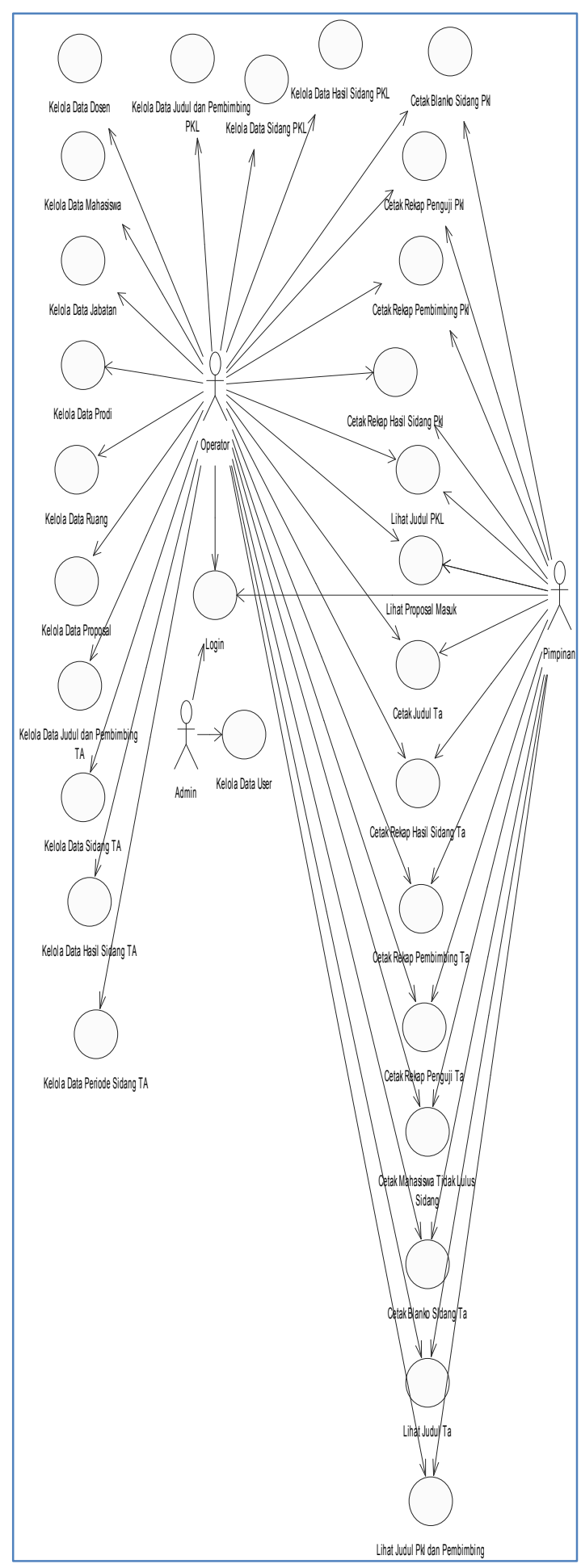

\begin{tabular}{|c|c|}
\hline Use Case & Deskripsi \\
\hline Login & Admin, operator dan pimpinan melakukan login \\
\hline Kelola Data Mahasiswa & $\begin{array}{l}\text { Operator dapat menambah, mengubah, menghapus, } \\
\text { mencari, dan menampilkan data mahasiswa. }\end{array}$ \\
\hline Kelola Data Dosen & $\begin{array}{l}\text { Operator dapat menambah, mengubah, menghapus, } \\
\text { mencari, dan menampilkan data dosen. }\end{array}$ \\
\hline Kelola Data Jabatan & $\begin{array}{l}\text { Operator dapat menambah, mengubah, menghapus } \\
\text { dan menampilkan data jabatan. }\end{array}$ \\
\hline Kelola Data Prodi & $\begin{array}{l}\text { Operator dapat menambah, mengubah, menghapus } \\
\text { dan menampilkan data prodi. }\end{array}$ \\
\hline Kelola Data Ruang & $\begin{array}{l}\text { Operator dapat menambah, mengubah, menghapus } \\
\text { dan menampilkan data ruang. }\end{array}$ \\
\hline Kelola Data Proposal & $\begin{array}{l}\text { Operator dapat menambah, mengubah, menghapus } \\
\text { dan menampilkan data proposal. }\end{array}$ \\
\hline $\begin{array}{l}\text { Kelola Data Judul dan } \\
\text { Pembimbing Tugas } \\
\text { Akhir }\end{array}$ & $\begin{array}{l}\text { Operator dapat menambah, mengubah, menghapus } \\
\text { dan menampilkan data Judul dan Pembimbing Tugas } \\
\text { Akhir. }\end{array}$ \\
\hline $\begin{array}{l}\text { Kelola Data Periode } \\
\text { Sidang Tugas Akhir }\end{array}$ & $\begin{array}{l}\text { Operator dapat menambah, mengubah, menghapus } \\
\text { dan menampilkan data periode sidang tugas akhir. }\end{array}$ \\
\hline $\begin{array}{l}\text { Kelola Data Sidang } \\
\text { Tugas Akhir }\end{array}$ & $\begin{array}{l}\text { Operator dapat menambah, mengubah, menghapus } \\
\text { dan menampilkan data sidang tugas akhir. }\end{array}$ \\
\hline $\begin{array}{l}\text { Kelola Data Hasil } \\
\text { Sidang Tugas Akhir }\end{array}$ & $\begin{array}{l}\text { Operator dapat menambah, mengubah, menghapus } \\
\text { dan menampilkan data Hasil sidang tugas akhir. }\end{array}$ \\
\hline $\begin{array}{l}\text { Kelola Data Judul dan } \\
\text { Pembimbing PKL }\end{array}$ & $\begin{array}{l}\text { Operator dapat menambah, mengubah, menghapus } \\
\text { dan menampilkan data judul dan pembimbing praktek } \\
\text { kerja lapangan. }\end{array}$ \\
\hline Kelola Data Sidang PKL & $\begin{array}{l}\text { Operator dapat menambah, mengubah, menghapus } \\
\text { dan menampilkan data sidang praktek kerja lapangan. }\end{array}$ \\
\hline $\begin{array}{l}\text { Kelola Data Hasil } \\
\text { Sidang PKL }\end{array}$ & $\begin{array}{l}\text { Operator dapat menambah, mengubah, menghapus } \\
\text { dan menampilkan data Hasil sidang praktek kerja } \\
\text { lapangan. }\end{array}$ \\
\hline Kelola Data User & $\begin{array}{l}\text { Admin dapat menambah, mengubah, menghapus dan } \\
\text { menampilkan data user }\end{array}$ \\
\hline $\begin{array}{l}\text { Cetak Blanko Sidang } \\
\text { Pkl }\end{array}$ & $\begin{array}{l}\text { Operator dan pimpinan dapat melihat dan mencetak } \\
\text { blanko sidang pkl }\end{array}$ \\
\hline $\begin{array}{l}\text { Cetak Rekap Penguji } \\
\text { Pkl }\end{array}$ & $\begin{array}{l}\text { Operator dan pimpinan dapat melihat dan mencetak } \\
\text { rekap penguji pkl }\end{array}$ \\
\hline $\begin{array}{l}\text { Cetak Rekap Pembimbing } \\
\text { Pkl }\end{array}$ & $\begin{array}{l}\text { Operator dan pimpinan dapat melihat dan mencetak } \\
\text { rekap pembimbing pkl }\end{array}$ \\
\hline $\begin{array}{l}\text { Cetak Rekap Hasil } \\
\text { Sidang Pkl }\end{array}$ & $\begin{array}{l}\text { Operator dan pimpinan dapat melihat dan mencetak } \\
\text { rekap hasil sidang pkl }\end{array}$ \\
\hline Lihat Judul Pkl & Operator dan pimpinan dapat mencari judul pkl \\
\hline Lihat Proposal Masuk & $\begin{array}{l}\text { Operator dan pimpinan dapat melihat dan mencetak } \\
\text { daftar proposal tugas akhir yang masuk }\end{array}$ \\
\hline $\begin{array}{l}\text { Cetak Daftar Judul } \\
\text { Tugas Akhir }\end{array}$ & $\begin{array}{l}\text { Operator dan pimpinan dapat melihat dan mencetak } \\
\text { daftar judul tugas akhir }\end{array}$ \\
\hline $\begin{array}{l}\text { Cetak Rekap Hasil Sidang } \\
\text { Tugas Akhir }\end{array}$ & $\begin{array}{l}\text { Operator dan pimpinan dapat melihat dan mencetak } \\
\text { rekap hasil sidang tugas akhir }\end{array}$ \\
\hline $\begin{array}{l}\text { Cetak Rekap Pembimbing } \\
\text { Tugas Akhir }\end{array}$ & $\begin{array}{l}\text { Operator dan pimpinan dapat melihat dan mencetak } \\
\text { rekap pembimbing tugas akhir }\end{array}$ \\
\hline $\begin{array}{l}\text { Rekap Penguji Tugas } \\
\text { Akhir }\end{array}$ & $\begin{array}{l}\text { Operator dan pimpinan dapat melihat dan mencetak } \\
\text { rekap penguji tugas akhir }\end{array}$ \\
\hline $\begin{array}{l}\text { Cetak Mahasiswa Tidak } \\
\text { Lulus Sidang }\end{array}$ & $\begin{array}{l}\text { Operator dan pimpinan dapat melihat dan mencetak } \\
\text { mahasiswa tidak lulus sidang tugas akhir }\end{array}$ \\
\hline $\begin{array}{l}\text { Cetak Blanko Sidang } \\
\text { Tugas Akhir }\end{array}$ & $\begin{array}{l}\text { Operator dan pimpinan dapat melihat dan mencetak } \\
\text { blanko sidang tugas akhir }\end{array}$ \\
\hline Lihat Judul Tugas Akhir & $\begin{array}{l}\text { Operator dan pimpinan dapat mencari judul tugas } \\
\text { akhir }\end{array}$ \\
\hline $\begin{array}{l}\text { Lihat Judul Pkl dan } \\
\text { Pembimbing }\end{array}$ & $\begin{array}{l}\text { Operator dan pimpinan dapat melihat dan mencetak } \\
\text { judul pkl dan pembimbing }\end{array}$ \\
\hline
\end{tabular}




\section{Definisi Use Case Pengelolaan Tugas Akhir dan Praktek Kerja Lapangan}

\section{Perancangan Model Use Case Diagram Pengelolaan Nilai Mahasiswa}

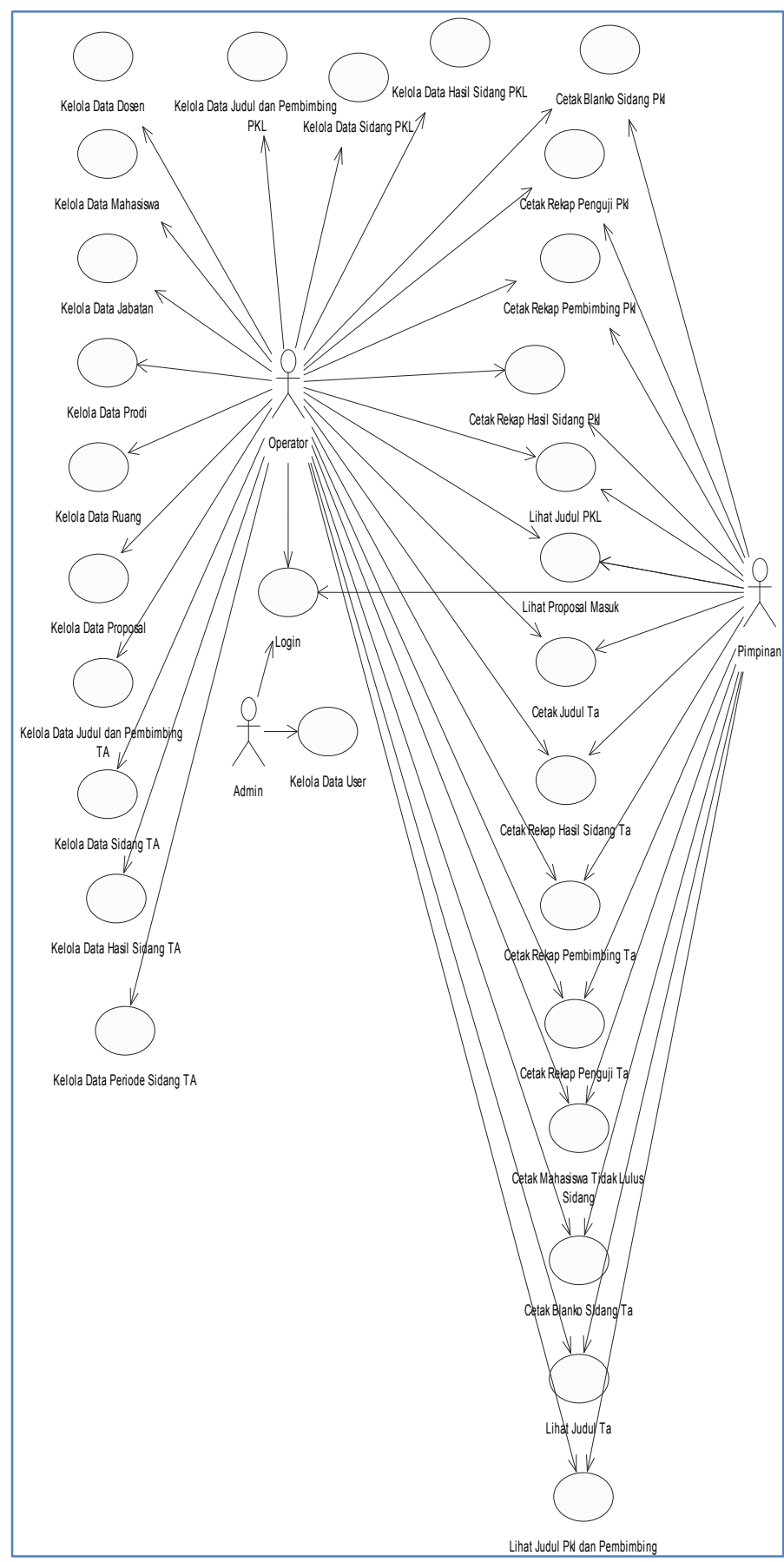

Definisi Use Case Pengelolaan Tugas Akhir dan Praktek Kerja Lapangan

\begin{tabular}{|c|c|}
\hline Use Case & Deskripsi \\
\hline Login & $\begin{array}{l}\text { Admin, operator dan pimpinan melakukan } \\
\text { login }\end{array}$ \\
\hline $\begin{array}{l}\text { Kelola Data } \\
\text { Mahasiswa }\end{array}$ & $\begin{array}{l}\text { Operator dapat menambah, mengubah, } \\
\text { menghapus, mencari, dan menampilkan } \\
\text { data mahasiswa. }\end{array}$ \\
\hline Kelola Data Dosen & $\begin{array}{l}\text { Operator dapat menambah, mengubah, } \\
\text { menghapus, mencari, dan menampilkan } \\
\text { data dosen. }\end{array}$ \\
\hline Kelola Data Jabatan & $\begin{array}{l}\text { Operator dapat menambah, mengubah, } \\
\text { menghapus dan menampilkan data jabatan. }\end{array}$ \\
\hline Kelola Data Prodi & $\begin{array}{l}\text { Operator dapat menambah, mengubah, } \\
\text { menghapus dan menampilkan data prodi. }\end{array}$ \\
\hline Kelola Data Ruang & $\begin{array}{l}\text { Operator dapat menambah, mengubah, } \\
\text { menghapus dan menampilkan data ruang. }\end{array}$ \\
\hline $\begin{array}{l}\text { Kelola Data } \\
\text { Proposal }\end{array}$ & $\begin{array}{l}\text { Operator dapat menambah, mengubah, } \\
\text { menghapus dan menampilkan data } \\
\text { proposal. }\end{array}$ \\
\hline $\begin{array}{l}\text { Kelola Data Judul } \\
\text { dan Pembimbing } \\
\text { Tugas Akhir }\end{array}$ & $\begin{array}{l}\text { Operator dapat menambah, mengubah, } \\
\text { menghapus dan menampilkan data Judul } \\
\text { dan Pembimbing Tugas Akhir. }\end{array}$ \\
\hline $\begin{array}{l}\text { Kelola Data Periode } \\
\text { Sidang Tugas Akhir }\end{array}$ & $\begin{array}{l}\text { Operator dapat menambah, mengubah, } \\
\text { menghapus dan menampilkan data periode } \\
\text { sidang tugas akhir. }\end{array}$ \\
\hline $\begin{array}{l}\text { Kelola Data Sidang } \\
\text { Tugas Akhir }\end{array}$ & $\begin{array}{l}\text { Operator dapat menambah, mengubah, } \\
\text { menghapus dan menampilkan data sidang } \\
\text { tugas akhir. }\end{array}$ \\
\hline $\begin{array}{l}\text { Kelola Data Hasil } \\
\text { Sidang Tugas Akhir }\end{array}$ & $\begin{array}{l}\text { Operator dapat menambah, mengubah, } \\
\text { menghapus dan menampilkan data Hasil } \\
\text { sidang tugas akhir. }\end{array}$ \\
\hline $\begin{array}{l}\text { Kelola Data Judul dan } \\
\text { Pembimbing Praktek } \\
\text { Kerja Lapangan }\end{array}$ & $\begin{array}{l}\text { Operator dapat menambah, mengubah, } \\
\text { menghapus dan menampilkan data judul } \\
\text { dan pembimbing praktek kerja lapangan. }\end{array}$ \\
\hline $\begin{array}{l}\text { Kelola Data Sidang } \\
\text { Praktek Kerja } \\
\text { Lapangan }\end{array}$ & $\begin{array}{l}\text { Operator dapat menambah, mengubah, } \\
\text { menghapus dan menampilkan data sidang } \\
\text { praktek kerja lapangan. }\end{array}$ \\
\hline $\begin{array}{l}\text { Kelola Data Hasil } \\
\text { Sidang praktek kerja } \\
\text { lapangan }\end{array}$ & $\begin{array}{l}\text { Operator dapat menambah, mengubah, } \\
\text { menghapus dan menampilkan data Hasil } \\
\text { sidang praktek kerja lapangan. }\end{array}$ \\
\hline Kelola Data User & $\begin{array}{l}\text { Admin dapat menambah, mengubah, } \\
\text { menghapus dan menampilkan data user }\end{array}$ \\
\hline $\begin{array}{l}\text { Cetak Blanko } \\
\text { Sidang Pkl }\end{array}$ & $\begin{array}{l}\text { Operator dan pimpinan dapat melihat dan } \\
\text { mencetak blanko sidang pkl }\end{array}$ \\
\hline $\begin{array}{l}\text { Cetak Rekap } \\
\text { Penguji Pkl }\end{array}$ & $\begin{array}{l}\text { Operator dan pimpinan dapat melihat dan } \\
\text { mencetak rekap penguji pkl }\end{array}$ \\
\hline $\begin{array}{l}\text { Cetak Rekap } \\
\text { Pembimbing Pk1 }\end{array}$ & $\begin{array}{l}\text { Operator dan pimpinan dapat melihat dan } \\
\text { mencetak rekap pembimbing pkl }\end{array}$ \\
\hline $\begin{array}{l}\text { Cetak Rekap Hasil } \\
\text { Sidang Pkl }\end{array}$ & $\begin{array}{l}\text { Operator dan pimpinan dapat melihat dan } \\
\text { mencetak rekap hasil sidang pk1 }\end{array}$ \\
\hline Lihat Judul Pkl & $\begin{array}{l}\text { Operator dan pimpinan dapat mencari judul } \\
\text { pk1 }\end{array}$ \\
\hline $\begin{array}{l}\text { Lihat Proposal } \\
\text { Masuk }\end{array}$ & $\begin{array}{l}\text { Operator dan pimpinan dapat melihat dan } \\
\text { mencetak daftar proposal tugas akhir yang } \\
\text { masuk }\end{array}$ \\
\hline $\begin{array}{l}\text { Cetak Daftar Judul } \\
\text { Tugas Akhir }\end{array}$ & $\begin{array}{l}\text { Operator dan pimpinan dapat melihat dan } \\
\text { mencetak daftar judul tugas akhir }\end{array}$ \\
\hline $\begin{array}{l}\text { Cetak Rekap Hasil } \\
\text { Sidang Tugas Akhir }\end{array}$ & $\begin{array}{l}\text { Operator dan pimpinan dapat melihat dan } \\
\text { mencetak rekap hasil sidang tugas akhir }\end{array}$ \\
\hline Cetak Rekap & Operator dan pimpinan dapat melihat dan \\
\hline
\end{tabular}




\begin{tabular}{|l|l|}
\hline $\begin{array}{l}\text { Pembimbing Tugas } \\
\text { Akhir }\end{array}$ & mencetak rekap pembimbing tugas akhir \\
\hline $\begin{array}{l}\text { Rekap Penguji } \\
\text { Tugas Akhir }\end{array}$ & $\begin{array}{l}\text { Operator dan pimpinan dapat melihat dan } \\
\text { mencetak rekap penguji tugas akhir }\end{array}$ \\
\hline $\begin{array}{l}\text { Cetak Mahasiswa } \\
\text { Tidak Lulus Sidang }\end{array}$ & $\begin{array}{l}\text { Operator dan pimpinan dapat melihat dan } \\
\text { mencetak mahasiswa tidak lulus sidang } \\
\text { tugas akhir }\end{array}$ \\
\hline $\begin{array}{l}\text { Cetak Blanko } \\
\text { Sidang Tugas Akhir }\end{array}$ & $\begin{array}{l}\text { Operator dan pimpinan dapat melihat dan } \\
\text { mencetak blanko sidang tugas akhir }\end{array}$ \\
\hline $\begin{array}{l}\text { Lihat Judul Tugas } \\
\text { Akhir }\end{array}$ & $\begin{array}{l}\text { Operator dan pimpinan dapat mencari judul } \\
\text { tugas akhir }\end{array}$ \\
\hline $\begin{array}{l}\text { Lihat Judul Pkl dan } \\
\text { Pembimbing }\end{array}$ & $\begin{array}{l}\text { Operator dan pimpinan dapat melihat dan } \\
\text { mencetak judul pkl dan pembimbing }\end{array}$ \\
\hline
\end{tabular}

\section{Skenario Use Case Diagram}

Berikut beberapa scenario Use Case Diagram dari sistem yang dibangun

a. Skenario Use Case Kelola Data Mahasiswa

Nama Use Case: Kelola Data Mahasiswa Aktor : Operator

Tujuan: Melihat, mengakses, mengelola data mahasiswa

Tabel 1 Skenario Use Case Kelola Data

Mahasiswa

\begin{tabular}{|l|l|}
\hline \multicolumn{1}{|c|}{ Aksi Aktor } & \multicolumn{1}{|c|}{ Reaksi Sistem } \\
\hline $\begin{array}{l}\text { Skenario Normal } \\
\text { mengelola data } \\
\text { mahasiswa. }\end{array}$ & $\begin{array}{l}\text { 2.Sistem menerima pengelolaan data mulai } \\
\text { dari tambah, cari, ubah, hapus, dan } \\
\text { menampilkan data mahasiswa. }\end{array}$ \\
\hline Skenario Lain & \\
\hline $\begin{array}{l}\text { 1.Operator } \\
\text { melakukan data } \\
\text { pengelolaan } \\
\text { secara tidak benar }\end{array}$ & $\begin{array}{l}\text { 2. Sistem tidak dapat dijalankan dan } \\
\text { menampilkan pesan kesalahan. }\end{array}$ \\
\hline \multicolumn{1}{|l|}{} \\
\hline
\end{tabular}

b. Skenario Use Case Kelola Data Dosen Nama Use Case: Kelola Data Dosen

Aktor: Operator

Tujuan:Melihat, mengakses, mengelola data dosen

\section{Tabel 2 Use Case Kelola Data Dosen}

\begin{tabular}{|l|l|}
\hline Aksi Aktor & \multicolumn{1}{|c|}{ Reaksi Sistem } \\
\hline Skenario Normal \\
\hline $\begin{array}{l}\text { 1. Operator } \\
\text { mengelola } \\
\text { data dosen. }\end{array}$ & $\begin{array}{l}\text { 2.Sistem menerima pengelolaan data mulai dari } \\
\text { tambah, cari, ubah, hapus, dan menampilkan data } \\
\text { dosen }\end{array}$ \\
\hline
\end{tabular}

\begin{tabular}{|l|l|}
\hline $\begin{array}{l}\text { 1. Operator } \\
\text { melakukan } \\
\text { pengelolaan } \\
\text { data secara } \\
\text { tidak benar }\end{array}$ & \\
\hline & $\begin{array}{l}\text { 2. Sistem tidak dapat dijalankan dan menampilkan } \\
\text { pesan kesalahan. }\end{array}$ \\
\hline
\end{tabular}

\section{HASIL DAN PEMBAHASAN Basis Data}

Basis Data pada Sistem Informasi Akademik Berbasis Web Jurusan Teknologi Informasi Politeknik Negeri Padang ini diimplementasikan dengan DBMS MySQL

Iables_in_dbsiaktif
tdatapk1
tdosen
tjabatan
tnahasisua
tpembimbingta
tperiodesidangta
tprodi
tproposalta
truang
tsidangpkl
tsidangta
tuser

\subsection{Antarmuka dan LaporanWeb}

Berikut adalah beberapa gambar tampilan antar muka web dan laporan web.

\section{a. Tampilan Awal Sistem}

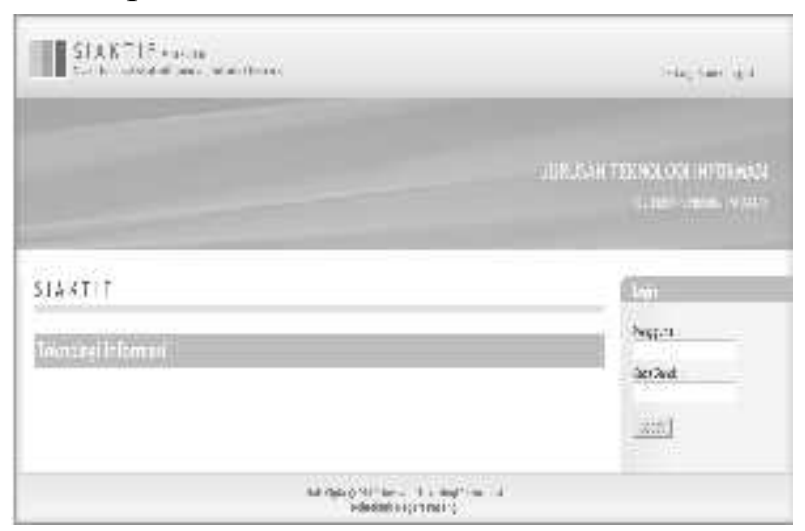


b. Form Entri Data Mahasiswa

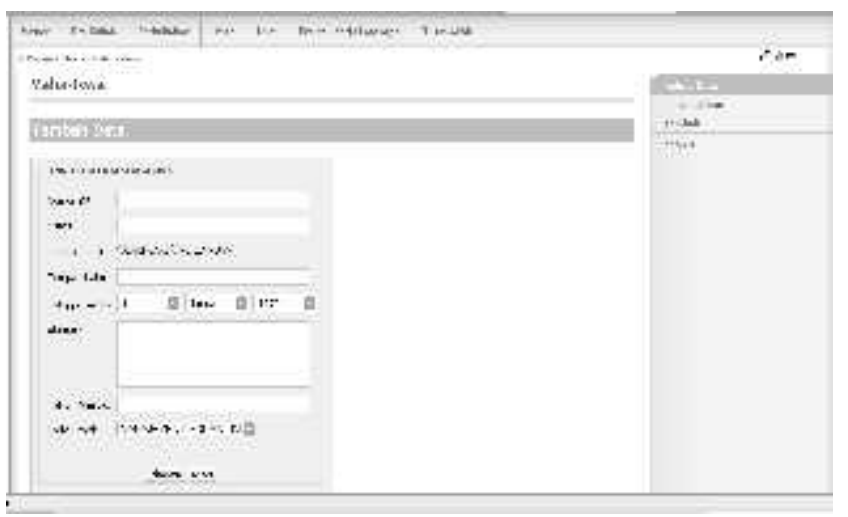

\section{h. Berita Acara Tugas Akhir}

\section{c.Form Entri Data Proposal Tugas Akhir}

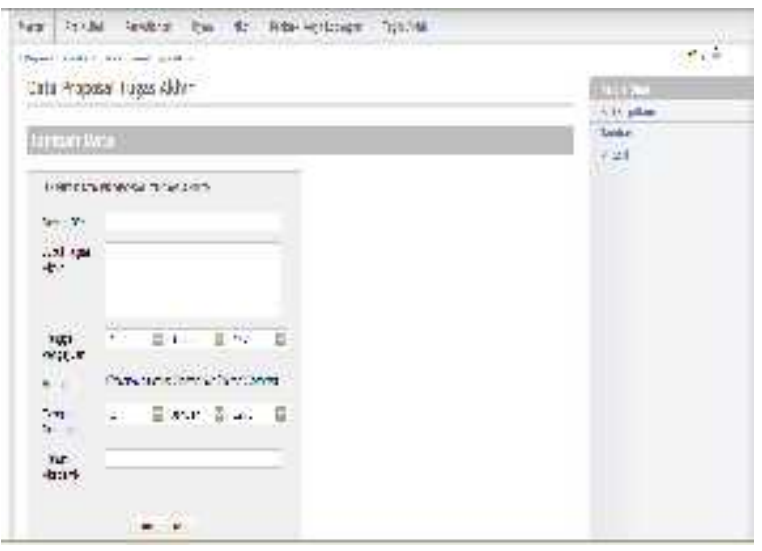

d. Form Entri Data Sidang Tugas Akhir

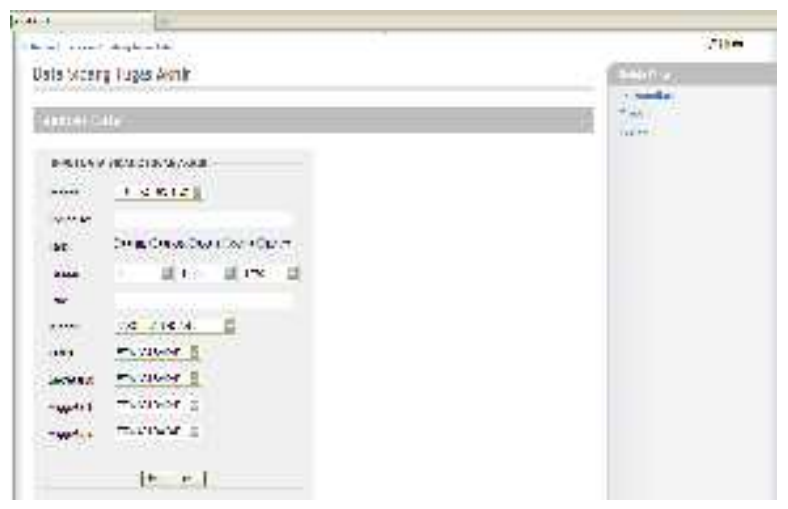

e. Form Entri Data Sidang PKL

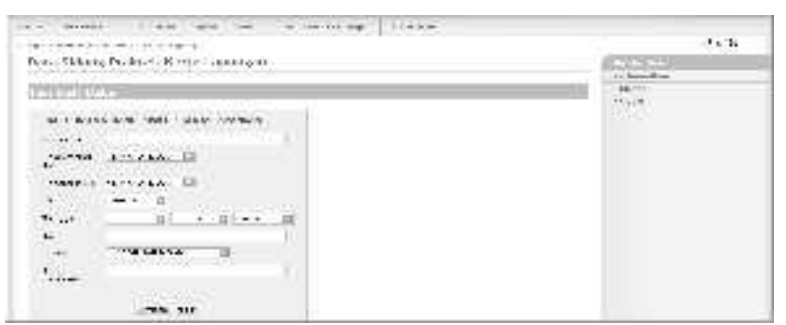

g. Laporan Jadwal Sidang Tugas Akhir

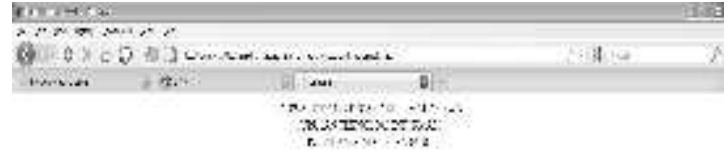

mex

\begin{tabular}{|c|c|c|c|c|c|c|c|c|}
\hline ㄴ. & $x:$ & Is & $x^{5}=$ & $\because 9$ & $z=2$ & ט:ב & Wiqu. & 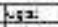 \\
\hline - & $x \times k:$ & $\Leftrightarrow$ & $x:<$ & Limen & (2):2 & 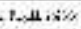 & $=-$ & $=1$ \\
\hline 4. & $\rightarrow \infty$. & - & 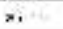 & w & $\rightarrow \ldots$ & s. & $\cdot$ & $n: 4$ \\
\hline
\end{tabular}

\section{thesext}

(1) $x+1$.

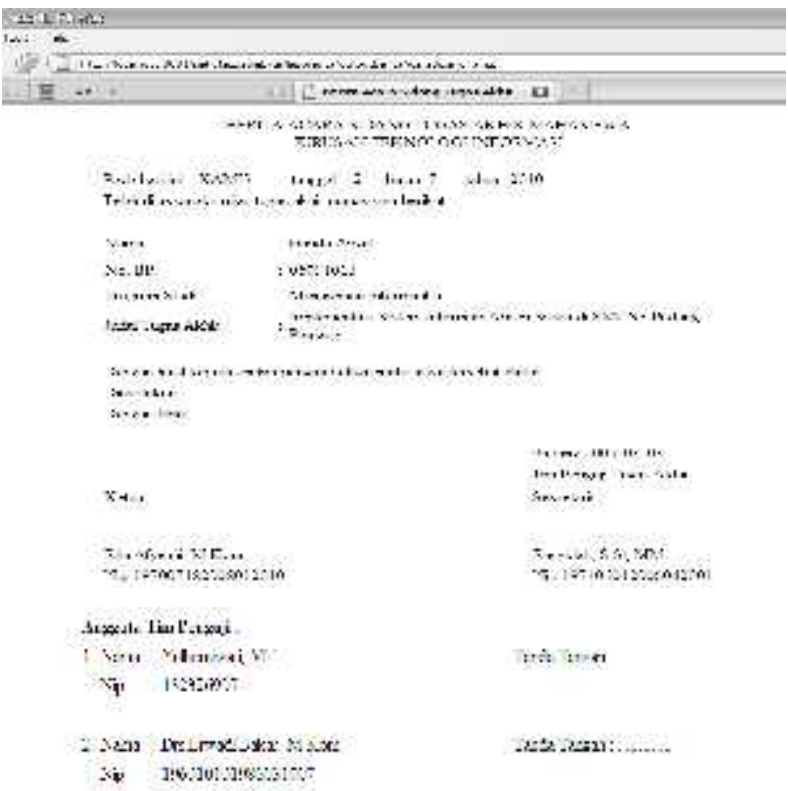

i.Laporan Rekapitulasi Hasil Sidang PKL

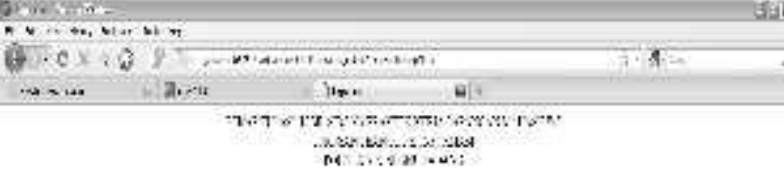

$\because=1 \quad \tan$.

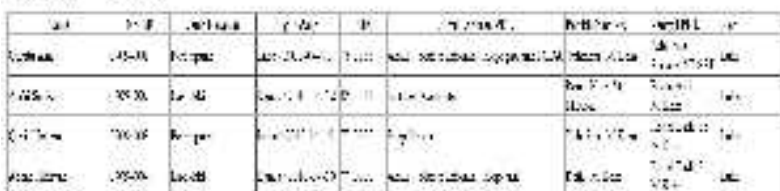

n.ris:y

bites

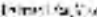

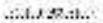


k.
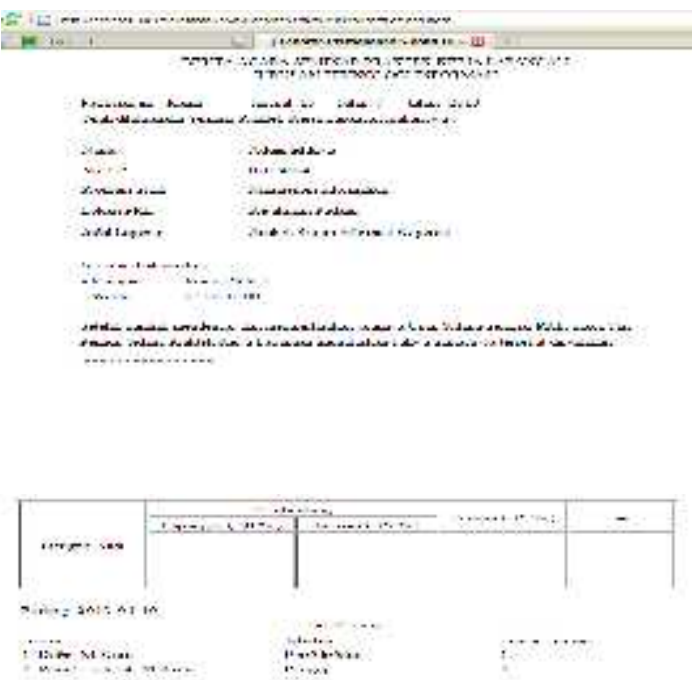

1. Indeks Prestasi Mahasiswa

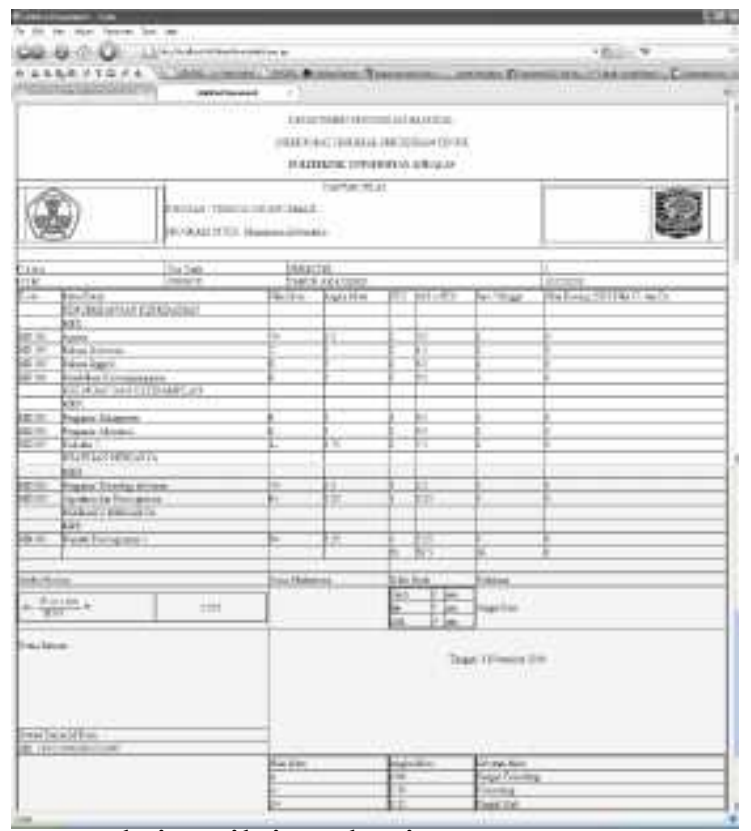

m. Transkrip Nilai Mahasiswa

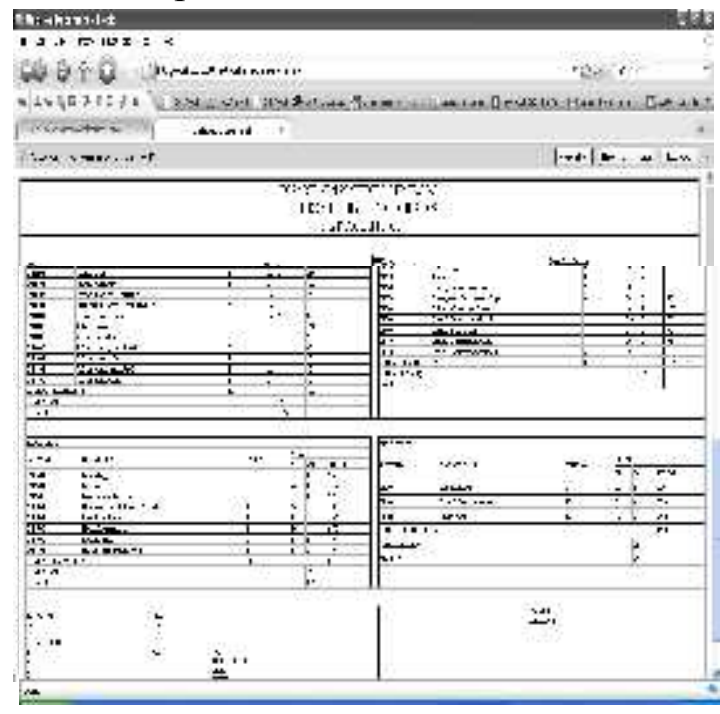

\section{Kesimpulan}

1. Dengan menggunakan sistem ini maka pengelolaan nilai, tugas akhir dan praktek kerja lapangan mahasiswa di Jurusan Teknologi Informasi Politeknik Negeri Padang dapat dilakukan lebih efektif dan efesien.

2. Informasi yang dibutuhkan dapat dilihat setiap saat dengan mudah dan kapanpun jika dibutuhkan serta penyimpanan datanya terjamin, aman dan tidak banyak memakan tempat.

3. Dengan menggunakan pemograman berbasis web ini, akan memudahkan di dalam pengelolaan data nilai, tugas akhir dan praktek kerja lapangan karena semua tabel telah terintegrasi di dalam sebuah database.

4. Kelemahan yang terdapat di sistem ini yaitu URL belum menggunakan parameter-parameter sehingga URL masih terlihat kurang efisien

\section{Saran}

Untuk pengembangan diharapkan agar URL menggunakan parameter sehingga terlihat lebih efisien dalam penggunaannya.

\section{Daftar Pustaka}

Hermawan, Julius : Analisa Disain dan Pemograman Obyek dengan UML dan Visual Basic.net Edisi I. Yogyakarta: Andi,

Jogiyanto HM. Analisa \& disain : Sistem Informasi Pendekatan Terstruktur Teori dan Praktek Aplikasi Bisnis. Yogyakarta : Andi, 2005.

Rickyanto, Isak. Belajar Sendiri Java Server Pages. Jakarta : PT. Elexmedia Komputindo, 2002.

Sanjaya, Ridwan : Pengelolahan database MySQL 5 dengan Java 2. Yogyakarta : Andi, 2005.

Wirtanto. Memahami Sistem Informasi. Bandung : Informatika Bandung, 2004. 
